\title{
Transsexualism in Spain: a Cultural and Legal Perspective
}

\author{
by Patrícia Soley-Beltran \\ Blanquerna - Universitat Ramón Llull (Barcelona) \\ Sociological Research Online, Volume 12, Issue 1, \\ < http://uww. socresonline.org.uk/12/1/soley-beltran.html> \\ doi:10.5153/sro. 1474
}

Received: 25 Jan 2006 Accepted: 14 Nov 2006 Published: 31 Jan 2007

\begin{abstract}
In this paper I will present an overview of the current legal, social and political situation of transsexual and transgendered people in Spain. The study is based on qualitative data gathered from in-depth interviews with transsexual people, transgendered activists and legal experts in Spain, including some aspects of a crosscultural comparison between Spain and the UK. The empirical study accounts for the development of social policies related to sex-reassignment and their evolution in the last decade in Spain, as well as for transsexual associations and activism, issues of social exclusion and prostitution.

The study on transsexuals consists of qualitative interviews with selected individuals of the transsexual community in Scotland and Catalonia about their life experiences. The analysis of the qualitative data explores the cultural assumptions underlying the legal aspects of sex-reassignment. Amongst other issues, the paper will deal with Spanish juridical procedures for documental reorientation and its potential role as incentive for undergoing sex-reassignment operation, and the performative character of transsexualism as a scientific category and folk gender myths in the shaping of gender. The cross-cultural comparison concerns scientific terminology and funding, as well as cultural and legal aspects of sexreassignment.
\end{abstract}

The study reveals the performative character of scientific categories, the mobilisation of conflicting discourses in the negotiation of meaning, the circularity and self-referentiality of the terms used both in expert and folk discourse. Moreover, the cross-cultural comparison demonstrates the conventionality of transsexualism as a scientific category and some of the ways in which social institutions act to perpetuate the erasure of gender fluidity.

\section{Keywords: Gender, Performativity, Sex-Reassignment, Social Policy, Transgenderism, Transsexuality, Spain}

\section{Introduction}

1.1 In this paper I will present an overview of the current legal, social and political situation of transsexual and transgendered people in Spain as well as some aspects of an empirical research carried out with transsexual people in Spain and in the UK. The research is theoretically informed by Judith Butler's performative theory of gender. The empirical study is based on qualitative data mainly gathered from indepth interviews with transsexual people, transgendered activists and legal experts in Spain. ${ }^{[1]}$

1.2 The study reveals the performative character of scientific categories, the mobilisation of conflicting discourses in the negotiation of meaning and the circularity and self-referentiality of the terms used both in expert and folk discourse. Moreover, the cross-cultural comparison demonstrates the conventionality of transsexualism as a scientific category and some of the ways in which social institutions act to perpetuate the erasure of gender fluidity.

1.3 The paper is structured in two parts. The first part "Methodology and Informants" introduces the empirical research: its working definitions, its conceptual framework, the informants, the methodology and technique employed, as well as the method for contacting the interviewees. The second part, "The Cultural and Legal Situation in Spain", is divided in four sections. In the first section, "Current legislation", I present an overview of the legal situation of transsexual persons in Spain, including the current legislation affecting all Spanish transsexuals, such as the documental reorientation and the real life test. In the second and the third sections, "Institutional tools for the social integration of transgendered persons" and "Transsexual Associations", I explore the strategies developed by some governmental institutions, such as the Basque and the Catalan Autonomous Governments, and transsexuals' associations in order to foster the social integration of transgendered people. The fourth section "Unfaithful citations" examines some issues arising from the cross-cultural comparison Spain/UK, such as the different understandings of the 
transsexual/transvestite distinction in its cultural context and transsexuals' documental reorientation, particularly attending to the differences in sources of funding of the sex-reassignment operations. The paper ends with some concluding remarks.

\section{METHODOLOGY AND INFORMANTS}

\section{What is a Transsexual?}

2.1 I conceive transsexualism as a knowledge category whose meaning is socially negotiated. The aim of the empirical research was to provide information about meaning and its negotiation. Nevertheless, previous to data gathering, I needed a working definition of 'transsexual' on which to base the selection of my interviewees. The question of physical intervention was decisive in narrowing the field of interviewees: I decided upon a working definition of transsexuals as those persons who interfere with their bodies at hormonal and/or surgical levels with the aim of becoming a different sex. Hence, I decided to focus solely on those people who had started some course of physical change at hormonal or surgical level. I made a further distinction between pre-operatives: subjects who were acting on their bodies at hormonal level only, and post-operatives: those who had surgical interventions.

2.2 One of the first questions I encountered when starting my research in the UK was the distinction between a transvestite and a transsexual (henceforth TV and TS) in medical taxonomy. According to medical standards, a transvestite or cross-dresser is a person who obtains sexual pleasure from dressing and acting as the opposite gender. These activities can be done in public or in the intimacy of an association or club with various degrees of regularity. A transsexual is a person who claims to have a sex that does not correspond with their gender. The mismatch between body and gender experienced by the transsexual is usually reported as an early childhood experience and it is accompanied by the strong wish to live as a member of the opposite gender not only for certain periods of time, like transvestites, but for the rest of her/his life. ${ }^{[2]}$ As a consequence of this, a transsexual is willing to interfere at both hormonal and surgical levels in order to align his/her body to the gender they feel they belong to. It is important to note that this constitutes another important definitional trait of transsexualism as medical category that separates it from transvestism. [3]

\section{Why Transsexuals?}

2.3 My starting point is a notion of gender "as an 'accomplishment' which requires the skills of constructing the body into a socially legitimate artifice" (Butler, 1988: 528). Since transsexuals very patently turn their bodies into artefacts, they exemplify the processes in an accentuated form to which we are all subjected in order to become men and women. Given that transsexuals' report experiencing a discontinuity between their body parts and the sexual pleasures that should be associated with them, their reports make apparent the constructed character of the body. Hence, by inquiring into transsexuals' sense of discontinuity we can expose the conventions that rule the ways in which we conceive certain body parts and desires as 'naturally' belonging to the category of female or male sex. The observation of transsexuals' practices, such as Garfinkel's study of Agnes, ${ }^{[4]}$ revealed the taken-for-granted appearance of gender to be a managed production. The choice of transsexuals as informants of the heterosexual hegemony flows readily from Butler's thought: "the strange, the incoherent, that which falls 'outside,' gives us a way of understanding the taken-for-granted world of sexual categorisation as a constructed one, indeed, as one that might well be constructed differently" (Butler, 1990: 110).

\section{The Informants}

2.4 The empirical study consists of qualitative interviews with selected individuals of the transsexual community in Scotland and Catalonia about their life experiences. The work was carried in Aberdeen, Edinburgh and Barcelona along the year 1998. The data analysis has been carried out on a total selection of twelve subjects: six British subjects (Jane, Brenda, Justin, Ronnie, Gwendolyn and Carol) and six Spanish subjects (Gabriel, María, Silvia, Pamela, Elsa and Elias). In my choice of interviewees I aimed for equal representation of female-to-male transsexuals, henceforth FTM, and male-to-female transsexuals, henceforth MTF, as well as for pre and post-operative individuals. See Table 1 for some basic information about the interviewees. In the final choice of interviewees I aimed for a proportionate representation of preoperative and post-operative transsexuals. ${ }^{[5]}$ In the table the sexual orientation is considered in the transgendered sex and the interviewees' real names have been substituted by pseudonyms. ${ }^{6]}$ 


\begin{tabular}{|c|c|c|c|c|c|c|c|}
\hline $\begin{array}{l}\text { INTERVIEW } \\
\text { NUABBER }\end{array}$ & NAME & $\mathrm{M} / \mathrm{F}$ & STATUS & NATIONALITY & $\begin{array}{l}\text { SEXUAL } \\
\text { ORIENTATION }\end{array}$ & AGE & PROFESSION \\
\hline 1,1 bis & Jane & MTF & Pre-operative & Bntish & Homosemul & 40 & Salmon furming \\
\hline 2 & Brends & MTF & Pre-operative & $\approx$ & Hetarosexuad & 41 & Civil servant \\
\hline 3 & Justin & FTM & Post-operative & - & Heterosexas & 76 & Retired eivil servant \\
\hline 4 & Ronnis: & FTM & Post-operative & - & Heterosexas & 31 & Unemployed \\
\hline 5 & Owendolyn & MTF & Post-operative & - & Heterosexual & 37 & Electronacs engineer \\
\hline 6 & Carol & MTF & Pre-operative & - & Aserual, homosemul & 38 & Banks manager \\
\hline
\end{tabular}

\begin{tabular}{|c|c|c|c|c|c|c|c|}
\hline 7 & Gobrit! & FTM & Pre-operative & Spanish & Hettrosexual & 27 & Cook \\
\hline 8 & Maria & MTF & Post-operative & - & Heterosexual & 41 & Communic ations engineer \\
\hline 9 & Salvis & MTF & Pre-operative & - & Heterosexual & 33 & Besutician, waitress \\
\hline 10 & Pamela & MTF & Pre-operative & - & Heterosexual & 18 & Hesth student \\
\hline 11 & Elsa & MTF & Pre-operative & - & Hetrosenas & 30 & Student, prostitution \\
\hline 12 & Elias & FTM & Postoperative & $\approx$ & Heterosexual & 24 & Labotatory technician \\
\hline
\end{tabular}

2.5 Establishing a cross-cultural comparison between Spain and the UK reveals interesting contrasts in so far as, albeit these two countries are not too distant culturally speaking, the radically different degree of the institutionalization of transsexualism as a pathology reveals both cultural variations concerning the folk notions of gender and transsexuality, as well as the performative character of scientific categories and the rich interdiscursive action taking place between experts and folk discourse. In the cross-cultural comparison I speak of national difference in a loose sense. The British interviewees came from different parts of the UK, including Scotland. The transsexuals interviewed in Barcelona also came from different parts of Spain. According to Spanish lawyer Fernández, a considerable number of Spanish MTF transsexuals originally came from the South of Spain (Andalusia, Murcia, Extremadura) and moved to bigger cities such as Madrid of Barcelona searching for anonymity. Indeed, four out of six of the Spanish interviewees were either sons of immigrants from the South of Spain or have moved into the city from another province.

2.6 It should be noted that the empirical study is based a small sample which might raise doubts about how far it can be generalised because of its limited scope. However, in spite of it being a small sample, it is not an inductive study, it presents consistent views and it offers rich informative material that opens many questions for further research. However, the reduced scope of the research and its qualitative approach imply that the findings are not a representative sample and should not be taken as the basis for statistical generalisation.

\section{Methodology and Technique}

2.7 The qualitative data collected in the fieldwork is examined by discourse analysis. Hence, I will consider language as a form of social action and I will investigate how texts and verbal accounts are constructed in order to reveal tacit and practical knowledge. I will also look for the linguistic repertoire of the informants, that is, for that range of terms, specific metaphors or stylistic constructions that reveal the interpretative practices embodied in their discourse. The main technique employed for obtaining the qualitative data has been in-depth interviews with a small sample of informants; the interviews were loosely structured with open-ended questions. This technique allowed freedom for the interviewee to talk about what s/he considered important and, thus, I kept guidance and direction to a minimum.

2.8 Although the main sources of data are the twelve selected interviews with transsexuals, I have also drawn from qualitative data gathered during one year of research that helped me familiarise myself and better understand transsexualism. These data were gathered through participant observation in the fourth Gender Dysphoria Conference (see Purnell 1996) which took place at Manchester University; and several interviews that took place between 1997 and 2006 with Sra. Maria Lluisa Fernandez, a Spanish lawyer specialising in transsexuals' cases; Sra. Natàlia Parés and Sra. Norma Mejía, from the Col-lectiu de Transsexuals de Catalunya (Catalonia Transsexual Association, henceforth CTC); Sra. Carme Vidal, Regiduria de la Dona i Drets Civils; Sr. Eugeni Villalbí, "Program for gays, lesbians and transsexuals"; and Sr. Victor Manuel from Berdindu, at the Basque country. To all of them I am greatly indebted. Other materials were also used, such as press and media reports, cartoon strips, documentaries, films, newsletters produced by transsexual associations, transsexuals' mail groups and so on. 
2.9 Contact with informants was established through several different channels. Initially I wrote official introductory letters to two doctors specialising in transsexualism, inquiring about the possibility of contacting some of their patients. The responses obtained through this channel were not very successful. Although I conducted two interviews in the informants' homes I could detect that they were very hesitant in their response and reluctant to disclose much about themselves. This was possibly due to suspicions about my intentions and confidentiality due to my contact with their doctor. A second channel that proved more successful was contacting the numerous transsexuals' associations. When the contact was not established through a doctor, I was able to present myself as a sympathetic researcher without psychological or medical prejudices who would keep their identities strictly confidential. Transsexuals appreciated the sort of attention and interest I was taking in them. This, together with my understanding and relaxed attitude, provided the right kind of atmosphere for confidentiality. The fact that I had no input whatsoever in their diagnosis was also important with regards to the interviewees' non-secretive attitude. My position allowed me to avoid the problem of data bias arising from data collected by people who are both researcher and diagnostician (Risman 1982: 320).

2.10 Thus, two thirds of the selected interviewees were contacted through an association (the exceptions being: Gwendolyn, Justin, Ronnie and Maria), and the interviews were conducted either in the associations' premises or in the interviewees' homes; these spaces were perceived as "neutral" or private ground where the transsexuals felt comfortable and secure. This issue might give rise to a methodological problem, namely that of not giving voice to those transsexuals who are not part of an association. However, as it will be explained in the forthcoming section on transsexuals' associations, the research taps onto the question of the "invisibilisation of transsexuality", that is, on those transsexuals who either do not want to be labelled as such nor being represented in the transsexuals' associations.

\section{THE CULTURAL AND LEGAL SITUATION IN SPAIN}

3.1 In this section I will present an overview of the legal situation of transsexual persons in Spain Although there are substantial variations in the way in which Spanish autonomous communities deal with transsexuality, the laws regulating transsexual change and its social status are the same for all the communities in the Spanish State, given that the power to legislate over these issues has not been transferred to the autonomous communities. Hence, laws are defined by the Spanish congress of Deputies and the Spanish Senate, based in Madrid, and not by the parliaments of the seventeen autonomous communities that form the Spanish State.

3.2 In the following, I will deal with the current legislation in Spain, the real life test and the documental reorientation procedures in Spain and draw some comparisons with the UK; I will also cover marriage and other certificates, transsexual associations, as well as the strategies developed by several institutions to foster the social integration of transsexual and transgendered persons. I will also comment on some aspects, such as the different understandings of the transvestite/transsexual distinction in folk culture, arising from the cross-cultural comparison Spain-UK.

\section{Current Legislation}

3.3 As a result of the amendment of the Spanish Penal Code in 1983, sex change operations ceased to considered as a castration crime. However, at the time, sex reassignment surgery was specifically included nor excluded in the catalogue of the services offered by the Seguridad Social (Spanish national health service). In 1995 a Royal Decree regulating the services offered by the national health service specified that sex-reassignment surgery was not funded by the state, the exception being intersexuality. The Decree did not refer to non-surgical treatment of transsexuality, such as hormone therapy or psychological attention. Thus, a new legal void was created, so currently transsexuals must attend private clinics in order to receive treatment (Martín 2004: 79-80). At present there is no specific law concerning transsexualism, although the Spanish Socialist Party (PSOE) has proposed a new Ley de la Identidad de Género (Law for Gender Identity), currently under discussion

3.4 The members of CTC, are very critical with the proposed bill since, according to them, it equates transsexuality with the sex-reassignment operation, for no rights could be obtained unless a sex-change operation had been performed on the alleged transsexual. In their view, the bill equated gender with sexual organs and since they believe that: "To be a woman is not a question of genitals" (Elsa), they feel that the proposal intends to support the fictive unity of the category of sex, and its importance in defining identity and social role (Wittig 1976). The CTC hopes that "social sex" becomes more important than genitals.

3.5 Although all Spanish transsexual associations have been pressing for free public funding (Martín 2004: 79), there are no publicly funded operations in Spain, with the exception of Andalusia and Extremadura, autonomous regions in the South of Spain. The public funding of sex-reassignment operations in Andalusia, carried out by the Servicio Andaluz de Salud (Andalusian Health Service) since 1999, has attracted a number of transsexuals to this Southern autonomous community in order to undergo the surgical procedures of sex change. Since 1999 around 100 operations have been performed, both to FTMs and to MTFs and currently there is a very long waiting list (4 years approximately). 
3.6 After the legal change of sex is accepted, the person will become a man or a woman for most purposes the exceptions being marriage and adoption. Nevertheless, according to lawyer Sra. Fernández, there are some cases of legally sanctioned marriages of transsexuals in Spain. These have been marriages between differently sexed people, that is, unions between a FTM and a woman, a MTF and a man, or a FTM and a MTF. These marriages are not, strictly speaking, regulated by the law but they have been made possible because the authorised person performing the marriage (a judge or a priest) have based the union on the sex of the partners as established in their legal documents. ${ }^{[7]}$ Currently there is a contradiction between the position of Spanish Supreme Court, contrary to the recognition of transsexuals' right to marriage, and the instances of ordinary courts sanctioning this right. Although the Supreme Court has recognised the right to a change of sexual identity in four occasions, it has ruled against the legality of transsexual marriages (López-Galiacho Perona 1998: 320-333). According to Natàlia Parés, the decision concerning transsexual marriages depends on the Dirección General de Registros y Notariado (General Office of Registry and Notary). ${ }^{[8]}$ Transsexuals' associations hope that the 2005 law legalising homosexual marriages in Spain (Law 13/2005, $1^{\text {st }}$ July) indicates new social attitudes and that it will pave the way for new legislation sanctioning transsexuals' marriages.

3.7 The current juridical debates about the recognition of transsexuality are intertwined with several debates, such as the legislation of de facto and homosexual marriages, as well as debates around sex as a relevant category determining a person's civil state. In certain works, such as Elósegui Itxaso (1999), the analysis of the juridical treatment of transsexuality leads to a discussion of four models of theoretical relations between sex-gender (sex and gender identity, sex and gender as independent factors, transsexuality and androgyny, sex and gender as related but not identical) aiming at determining the best model of gender relations in order to achieve a more equitable society for women (Elósegui Itxaso 1999: 118-125). Although, on the wake of the European Parliament resolutions and the European Council (1989), there have been calls for a full legislation of transsexuality in Spain for almost a decade now (LópezGaliacho Perona 1998: 364-368), opposed views co-exist. Whereas some authors, such as Elósegui Itxaso (1999), are opposed to the full recognition of transsexuals juridical rights, others, such as López-Galiacho Perona (1998), advocate for the unrestricted recognition of these rights - including marriage with a person of the opposed sex - as means to avoid discrimination of transsexual persons in their "new" sexual identity. ${ }^{[9]}$

\section{Institutional Tools for the Social Integration of Transgendered Persons}

3.8 The Basque government was the first in developing a publicly funded service addressed to homosexual and transsexual people: Berdindu. Berdindu was founded in 2002 and it is funded by the Departamento de Vivienda y Servicios Sociales (Department of Public Housing and Social Services) of the Basque Autonomous Government. Its functions are to provide information services, legal assessment and psychological attention. It also aims to promote new policies and informing public opinion through consciousness raising campaigns. The word Berdindu is a pun in Basque language, since it both means "to make equal" (referring to its mission: to achieve equal rights), and "it doesn't matter" (to convey the message: we do not mind about your sexual orientation).

3.9 The second program developed in Spain, the "Programa de Información y Atención a Homosexuales y Transexuales", was launched in 2003 by the Autonomous Community of Madrid. The program is addressed to homosexual and transsexual persons and their families and social milieu. It provides formation, information, consulting and mainstreaming for civil servants, professionals working in the private sector and general population.

3.10 The third program, Programa per al col·lectiu, gai, lesbià i transsexual (Program for gays, lesbians and transsexuals), has been developed by the Generalitat de Catalunya (Catalan Government) to support associations of gays, lesbians and transsexual people, to foster the law for adoptions, and to promote a change of attitudes in the Catalan government and in the society in general. One of its first activities has been organising an exhibition to commemorate the $35^{\text {th }}$ anniversary of the gay, lesbian and transsexual movements in Catalonia (Villalbí 2005). ${ }^{[10]}$

\section{Transsexual Associations}

3.11 According to Ramos Cantó (2003: 125), transsexual associations in Spain first appeared in the 1970s. Sra. Natàlia Parés, president of the Federación de Asociaciones de Transexuales (FAT- Federation of Transsexuals' Associations) gathering several transsexuals' associations in Spain, estimates that there are around 8.000 transsexuals in Spain. Although transsexual associations has exploded in recent years, ${ }^{[11]}$ these associations generally do not have more than very few members, the exception being the Grup de Transexuals Masculins de Barcelona (GTMB), an association of FTM transsexuals which has around 100 members. ${ }^{[12]}$ Transsexuals' associations in Spain defend transsexualism as a medical condition and a socially acceptable category of identity through campaigns, demonstrations, appearances in the media, 
networking with national and international associations and other activities, addressed both to the general public as well as to the public institutions. Spanish associations aim to normativise the category of transsexualism in order to construct the transsexual community as a social group able to defend their rights.

3.12 Transsexuals' sense of identity is partly structured and maintained through their belonging to support networks which tend to take place even before the beginning of their transformation. Meeting transsexuals in a more advanced stage of transformation provides "a model for the future! Moreover, a model for achievement: if I've achieved it (the change), you too" (Elias). Through transsexuals' associations, interviewees acquired a new net of acquaintances and thus relieved their feelings of isolation by making them feel part of a group (Brenda), helping them to assume their identity as such - at times by providing support also to their families (Jane), and encouraging them to perceive themselves as deserving cultural subjects: "this is a way of living!" (Brenda). Such associations also function as informal channels of information on treatments, doctors, and so on, although, as I will show in the following section, Spanish transsexuals often trust each other more than the medical establishment.

3.13 Group relations between homosexual, transvestite and transsexual associations reveal tensions between the normativisation of transsexuality and potentially dissident behaviour concerning the Heterosexual Matrix. The pressure on UK transsexuals to distance themselves from homosexuality in order to conform to normative medical standards is also reflected in the fluctuating relations between gay and transvestite groups and transsexuals' associations. After years of distance and distrust, TS, TV and homosexual groups joined forces in the Gendys' 96 conference. However, this trend reversed and the tendency is again to mark a distance between homosexuals, transvestites and transsexuals. This oscillation reflects a tension between the advantages offered by conforming to medical categories - given that medical diagnosis implies a free operation - and the shortcomings of being perceived as condemnable and subversive of male/female distinctions by associating with homosexual or transvestite groups under the umbrella label of 'transgenderism'. Nevertheless, as shown in Table 1, some UK transsexuals identify as homosexual in their new identity.

3.14 Regarding group relations the situation is also different in Spain where "the transsexual movement (...) in its beginnings was usually diluted within the gay movement (...) transsexuality was perceived as an exacerbated manifestation of homosexuality" (Ramos Cantó 2003: 125, my translation). Since the seventies a gradual process of differentiation between the gay liberation and the transsexual movement took place as conceptual differences between the terms homosexuality and transsexuality were drawn. After a period of confrontation, gay and transsexual activism has reunited again under the GLBT (Gay, Lesbian,

Bisexual, Transsexual) label albeit from differentiated associations. ${ }^{[13]}$ In Barcelona, the first local transsexual group, the CTC, was in its origins unproblematically linked to homosexual associations, with which it still maintains a cordial relationship, and defends freedom of sexual choice. Nevertheless, often in their discourse Spanish transsexuals are concerned with marking a difference with homosexuality as an identity category, as becomes clear in the following quote: "for instance, when we have been invited to a TV program they always ask me: 'are you homosexual?' The thing is that, as transsexual, I can be hetero, I can be gay, I can be bisexual... As a person I can have many sexual tendencies, I don't have to restrict myself to hetero" (Gabriel). Here, Gabriel seems to be reacting against a Spanish folk belief that equates transsexuals with homosexuals by maintaining that transsexualism is not about sexuality at all, hence it is not about homosexuality or any other form of perceived sexual deviance. In sum, whereas Spanish interviewees had no qualms about allying with homosexual groups, British associations avoid such political alliance in order to avoid connotations of sexual perversity and maintain their identity as a medical predicament in agreement with normative medical definitions. Professionally the social situation of both groups is also markedly different, since Spain presents higher discrimination against transsexuals in their jobs and higher incidence of prostitution amongst transsexuals.

3.15 As mentioned above, transsexuals' associations aim to normativise the category 'transsexual' in order to integrate socially. As a result of these efforts transsexuality "is getting more and more normal" (Justin), and transsexuals are becoming a very organised community spanning several countries. ${ }^{[14]}$ However, some individuals do not even want to be classified into the category 'transsexual' to argue for social acceptability. Instead they insist on their wish to fit in with 'normality' by becoming invisible in their new sex: "I don't want to be / a minority group! I don't want to be labelled a transsexual! [...] I don't want to be pigeonholed as a minority group or whatever" (Ronnie).

3.16 Ronnie's position is a way for transsexuals to avoid abjection and gain acceptability, namely the "invisibilisation of transsexuality" (Silva): "if one has a favourable judicial sentence, one has changed sex, one has full recognition in documentation and nothing is known about your past, then to all practical effects one is already a woman like any other [...] if nothing is known about one's past and one is a normal woman with the appearance of a conventional woman, one has got it more easy to, to, that is, to be included within normality" (Silvia). Hence, when transsexuals successfully pass and, like Justin, "didn't tell anyone" (Justin), then "as far as I know, most society doesn't know" (Gwen). Gwen is for invisibility: "some people might want to stand up and challenge society and say: this isn't right!. But I think / political correctness has gone totally overboard and all this stuff that all minority groups have to get that attention. If everybody just gets on with life will be much better all round". Other transsexuals, such as Pamela, approach an 
association for support and information during the early stages of their change and completely dissociate themselves from the group once the transsexualisation has been successfully completed.

\subsection{According to Sra. Natàlia Parés, president of the Spanish Federación de Asociaciones de} Transexuales (FAT- Federation of Transsexuals' Associations), in spite of the numerous transsexual associations in Spain, transsexual people rarely step into action, the exception being Governmental bills forbidding prostitution in public spaces. Given the important number of MTF who work as prostitutes in the streets ( $85 \%$ of transsexuals in Barcelona, according to the CTC) this type of bills typically are of great concern to transsexual people. Indeed, one of the oldest transsexuals' groups in Spain, AET Transexualia based in Madrid (http://www.transexualia.org), was founded in 1987 in order to organise transsexual prostitutes.

\section{Unfaithful Citations ${ }^{[15]}$}

3.18 One of the most striking differences between the UK and Spain concerns the negotiation of meaning between different types of knowledge: medical, public, and private. Clearly, there are distinct emphases placed on the correct citation of medical platitudes between the UK and Spain; the citation of the transvestite/transsexual (henceforth TV/TS) distinction is a conspicuous example, as the transsexual/homosexual and the sex/gender distinctions. These phenomena might be due to the disparity in the sources of funding for medical treatment between the two countries, but they are also mainly related to cultural differences affecting the processes of meaning negotiation carried out by subjects themselves.

3.19 British interviewees tend to emphasise "the big difference between transvestite and transsexual" (Jane). The stress in differentiating between TV and TS in the UK might be due to the stronger influence of the psychiatric model in that country. The model requires that transsexuals base their claim for a sexchange operation in an identity problem. Since transvestites are considered as persons who cross-dress not because of a problem with their sexual identity but for sexual arousal, transsexuals need to distance themselves from them. To be associated with transvestism has practical consequences since, in order to obtain permission for sex-reassignment surgery in the National Health Service (henceforth NHS), one needs to be diagnosed as gender dysphoric. Therefore, it is in the best interest of transsexuals to make clear that they do not obtain sexual arousal from cross-dressing but that this activity merely obeys a profound feeling of belonging to the other sex.

3.20 If NHS requirements influence the concern for the correct citation of the standard narrative in the UK, we should expect a weaker normative citation in Spain where there is no public finance for sexreassignment. Indeed, the evidence gathered in my research shows that the citation of medical standards is unfaithful not only with regards to the meaning of the term 'transsexual', but also concerning transsexuals' practices. ${ }^{[16]}$ For instance, Spanish transsexuals tend to support freedom of sexual orientation privately and publicly, unlike their UK counterparts who do not so spontaneously declare homosexual feelings, nor pronounce on matters of sexual freedom. Undoubtedly, the lack of public funding plays a role in Spanish transsexuals' lack of interest in fitting with medical categories, as Gabriel makes explicit: "since you don't have it paid by the Seguridad Social (Spanish public health service), you don't have to justify anything. You go with your money... ta, ta, ta [making a gesture of paying by piling bills]". In Spain the situation is completely different since, with the exception of the Andalusian community, the Seguridad Social does not cover sex-change surgery and only in a very few instances hormonal treatment (exclusively for FTM). Therefore, Spanish transsexuals tend to approach a private clinic and cover the costs of their treatment themselves. Hence, the lack of public financing of the operation effectively frees Spanish transsexual subjects from the economic stimulus to define themselves in conformity with medical standards.

3.21 There are also significant cultural differences concerning documental reorientation between Spain and the UK that might spring from the lesser medicalisation of transgenderism in Spain. In the UK documental reorientation is part of the real life test and a precondition for the operation; documental reorientation is only ever partial and documents are generally less significant than in Spain. Given the personal and social importance of names it is no surprise that documental reorientation is an issue of great relevance for transsexuals: "the change of documents is very important. Even more than the operation" (Gabriel). Documental reorientation is an important part of the entire gender reorientation process (Petersen, 1995: 142), particularly in Spain, where the Documento Nacional de Identidad, an identity card all Spanish citizens are obliged to posses, is ubiquitous in social life. Spanish transsexuals expect the documental reorientation will increase social acceptance: "after all the administrative procedures that we must go through in order to change identity, to get an ID that is appropriate to our appearance, I suppose that (society) will be already fine, right? (...) Because one has combined everything, right? One already has the ID card! One has to carry it in one's mouth for absolutely everything!" (Pamela).

3.22 In Spain however the change of name takes place after the operation in MTF and it is based on a sort of informal real life test. Spanish juridical procedures for the management of gender reassignment operations offer some insight into gender as a self-referential process. In order to achieve the legal change of sex after a sex-change operation and the change of name (two different procedures), Spanish transsexuals must present a request to a court. Transsexuals' lawyers argue their case making use of an 
ancient doctrine of civil law called "Fumus de bon dret", also known as the theory of appearance of good justice, that protects appearance or fiction. ${ }^{[17]}$ Given that Spanish judges assume that sex is a purely biological and chromosomal category, ${ }^{[18]}$ lawyers argue for a widening of the notion of sex that includes social, psychological, and functional factors. To support this wider view and persuade the judges of the transsexual's suitability for the legal change of sex, lawyers appeal to the doctrine of appearance of good justice. They do so in an indirect manner by requesting a change of name at the same time as the claim for the change of sex. The purpose of the change of name request is not only to fulfil the transsexuals' wish to take a new name (to feminize their own is an easier option in the juridical system); there is also a strategic reason. The second purpose of the request is served by the mechanisms involved in the procedures for the change of name. These procedures involve investigating whether this person is known in his/her social surroundings by the name he/she wishes to adopt, ${ }^{[19]}$ by conducting interviews with colleagues, neighbours, family, friends, and so on, of the individual in question.

3.23 This evidence not only gives testimony of the familiarity of the individual's social milieu with the requested name, it also illustrates, in an indirect fashion, the level of social acceptance in his/her 'new' sex. Social acceptance confirms the transsexuals' right to a new name by showing that he/she possesses the 'right' and 'proper' appearance for the new sex and conducts herself/himself according to the prescribed behaviour for his/her sex. Since, as Kessler and MacKenna showed, social acceptance constitutes membership, the procedures for the change of name support the claim for the legal change of sex. In this manner, by making indirect use of the doctrine of appearance of good justice through the procedures that support the claim for the change of name, lawyers show that transsexuals fulfil the requirements of the 'right' appearance - that is, they fit the HM's standards of identity - and argue for the judges' sanction of what is a de facto situation.

3.24 Therefore, the decision of the judicial authorities for accepting the legal change of sex is settled on the basis of whether the person in question is taken to be a man or a woman by his/her social milieu. This is clearly a self-referential process, for the transsexual is socially sanctioned as being a man or a woman by the legal authorities on the basis of the social acceptance of their gender previous to the investigation. The question of documental reorientation illustrates the self-referentiality of gender rules since it shows their conventionality and how rules are not laid down in advance but decided by the collective. As consequence, the definition of transsexualism and its social acceptance depends on a collective assessment represented by those who hold authority to decide: the social milieu, the medical profession and judges. ${ }^{[20]}$ As a consequence, in the UK the medical profession holds great power to direct gender policing, whereas in Spain the legal establishment also plays an important part in directing social routines.

3.25 Documental reorientation is equivalent to social sanctioning of change. It enables transsexuals to pass more successfully and to establish their identity with the backup of legal authority. Moreover, according to Silvia, documental reorientation functions as a sort of incentive for the sex-change operation since it is a pre-requisite for renewal of documentation: "people tend to operate [...] not searching for, for pleasure but for recognition as female, that is, to the effect of documentation, rights, judicial purposes" (Silvia). After the operation: "if you have a judicial sentence that recognises your rights [...] integration is easier because one fits better with the standards" (Silvia). ${ }^{[21]}$

3.26 It is also significant that, unlike their UK counterparts, no Spanish transsexuals hinted that they were using the interview as a rehearsal, nor had they assumed I had a deeper knowledge on issues of transsexualism than them; on the contrary, they often adopted a didactic tone to enlighten me about what transsexualism was about and to make clear its distinction from transvestism. The didactic attitude of Spaniards co-exists with more variation at the personal level than their UK counterparts. The self-narratives of Spanish interviewees include an element of a political stance in so far as they regularly criticise social conditioning, they resist hegemonic gender platitudes as constraining, cite them from a critical standpoint, aim to subvert moral order, and use the notion of gender as a sociological category.

3.27 According to my interviewees, it seems that, in general, Spanish transsexuals read less literature on transsexualism (it is also less available) than their UK counterparts and rely instead to a greater degree on their friends as source of information for self-medication: "I was paying more attention to my pals. Yes,

look... maybe I'm a bit old-fashioned, aren't I?" [22] Indeed, Spanish transsexuals do not keep 'OTF' files ${ }^{\text {[23] }}$ and only well 'informed' MTFs and FTMs use the term 'transsexual', while the general public uses 'travesti' for MTF. These groups of 'informed' transsexuals tend to be also those politically motivated enough to be concerned about making the medical categories known and properly applied. All Spanish interviewees displayed a didactic attitude often expressed in a constant shift from the particular to the universal, that is, from using personal pronouns to making general references to the category 'transsexual'. Spanish transsexuals clearly aim to disseminate and establish basic information about transsexualism as a medical condition and cite the medical standard narrative to argue for social acceptance and legitimation of sexreassignment with a view to achieving public coverage of the operation. ${ }^{[24]}$ Hence, in Spain only politically motivated transsexuals bother about making the normative medical category 'transsexual' known and 'properly' applied since the authority of medical discourse legitimises sex-reassignment. 
modernity; in a way, they regard higher medicalisation, such as in the UK, as indicative of a more rational, superior and advanced society than their own. This view is also visible in so far as Spanish interviewees tend to assume that sexual roles and identities are less marked in the UK than in Spain. For instance, in the context of discussing Spain's double standards concerning men and women's sexuality, Silvia expresses the belief that British culture is not as sexist with regards to sexual morals and does not have so strongly marked sexual roles.

3.29 In a much more accentuated form than their UK counterparts, Spanish transsexuals criticise the medical profession for not being well acquainted with the condition of gender dysphoria: "the thing is that in Spain, I don't know what is like in the rest of, I think that / they don't really know what transsexuality is" (Silvia) $^{[25]}$. Paradoxically, doctors are their own best advocates as the heralds of modernity in front of what transsexuals perceive as a backward moral order which condemns transgenderism. ${ }^{[26]}$ However - and in contrast with their belief on the supremacy of states with higher institutionalisation of medicine, such as the UK - Spanish transsexuals do not seem to be very prepared to acquiesce with medical standards and can be quite critical of the medical establishment: "biology! well it can pursue its own speculating ways, for often they say certain things that one doesn't want to argue with because they live within their corporativism and within their science and... whatever they say, well, many times 'goes to Mass' ${ }^{\text {[27] }}$, doesn't it? Another question is whether I obey them or not..." (Elsa). Science is criticised for being "antihuman because it is more concerned, it gives more importance to one chromosome in my cells than to the sum total of my cells which is me, isn't it?" (Elias). Spanish transsexuals accuse doctors of making a profit out of them: "they demand a psychological-psychiatric test, that is completely stupid. It is just a way of getting money out of you. It is a way of stealing with a white glove, right?" (Gabriel). Moreover, in the context of discussing the proposed new law of gender identity, most specifically, whether the diagnosis should be issued by any GP or it should exclusively fall into the hands of specialists, Silvia insists "yes, specialists... in fucking people."

3.30 Given the repression and public invisibility of transsexuals in Spanish history, most papers on transsexualism currently published in Spain tend to be either a general introduction to its definition, its history and to the debates developed in English speaking countries, or governmental reports advising on its legal situation. ${ }^{[28]}$ Spanish anthropologist Nieto notes the difficulty of defining a "label-concept" for transsexuality since all classifications exclude a continuum necessary to capture, for instance, the difference between a transvestite and a transsexual - Nieto uses the term "travestido" to refer to the British terms "transvestite" and "cross-dresser" (Nieto 1998: ft. 9, p. 21). Although I disagree with his term usage, since I think that the terms "transvestite" and "cross-dresser" should be differentiated in Spanish (for instance by using "travestido" and "transformista" respectively), I share Nieto's point on the difficulty of capturing the gender continuum. However, given categories themselves are technologies for gender "normalization" regulated by social institutions, such as juridical power, it is not surprising that they erase gender fluidity, for this is precisely one of its aims.

3.31 In sum, transsexualism as a medical condition is still less well known in Spain than in the UK due to the lesser influence of the humanist discourse of psychiatry in comparison with the UK. The lesser prominence of transsexualism in Spain is also clearly linked to the lower influence that psychiatric humanism has had over the prevailing moral order. In its turn, the lack of public funding so far and low general income of potential transsexual clients makes it less worthwhile economically for the specialisation of surgeons or the establishment of more private clinics. However, the current trend is to "normalise" transsexualism as a medical condition through the establishment of clearly defined gender identity categories.

\section{CONCLUSIONS}

4.1 In this paper I have presented the legal situation of transsexualism in Spain while the empirical study on the institutionalization of transsexualism as a pathology reveals both cultural variations concerning the folk notions of gender and transsexuality, as well as the performative character of scientific categories and the rich interdiscursive action taking place between experts and folk discourse. The study of the process of documental reorientation in Spain also shows the self-referentiality of the category of gender. The crosscultural comparison Spain/UK exposes differences in several areas, such as transsexuals' categorisation in scientific and public discourse (as, for instance concerning the term travesti) and their citation of medical standards in social context. Such differences illustrate the on-going negotiation of meaning between transsexuals, social institutions and the medical profession, as well as the construction and deconstruction of gender and transsexualism in different cultures.

4.2 The empirical study reveals the circularity and self-referentiality of the terms used both in expert and folk discourse. It also identifies the ways in which sanctions protect the meaning stability of gender categories. Transsexuals' accounts and practices corroborate the importance of gender as surface performance and substantiate the view that repetitive citation of the folk and medical categories shape the gendered body. Moreover, the cross-cultural comparison demonstrates the conventionality of transsexualism as a scientific category.

4.3 To summarise, in this paper I have introduced the legal situation of transsexual persons in Spain as well 
as the most advanced policies aiming to eradicate social discrimination. The legal procedures surrounding sex-reassignment and its evolution reveal changing cultural perceptions on transsexualism, as a result of the development of new attitudes to gender in Spain. However, the study of the process of documental reorientation in Spain as a real life test of sorts and the role of medical definitions of transsexuality reveal some of the ways in which, despite noticeable advances, social institutions still act to perpetuate the erasure of gender fluidity.

\section{Notes}

${ }^{1}$ I am greatly indebted to all the transsexual people who very generously granted me interviews or informal chats as well as to all the other informants mentioned in the text. Part of the research here presented was funded by the Carnegie Trust for the Universities of Scotland and the Charitable Foundation of the British Federation of Women Graduates; I am very grateful to both for their support.

2 Jane refers to the different TV/TS desires as follows: "as a transvestite to occasionally cross-dress or as a transsexual to plainly be female" (Jane).

${ }^{3}$ As will be explained later in the text, the TV/TS distinction presents some significant variations in Spain.

${ }^{4}$ Garfinkel's pioneering study of Agnes firstly revealed the taken-for-granted appearance of gender to be a managed production. The observation of Agnes' practices became Garfinkel's source for treating "normally" sexed persons as "cultural events in societies whose character as visible orders of practical activities consist of members' recognition and production practices" (Garfinkel 1967: 180-1). Agnes' passing devices revealed the artificiality of the normally sexed person as a cultural accomplishment achieved by following collectively shared and monitored rules. Garfinkel's study was further developed by Kessler and MacKenna (1978).

${ }^{5}$ Again there is a variation in the way in which the relation between transsexuality and surgical intervention is understood in the UK and in Spain.

${ }^{6}$ For the complete study, please see Soley-Beltran (2001).

7 There were two much publicised cases of transsexual marriages in 2003 , although there are registered cases as early as 1993 (a FTM marrying a woman) and 1990 - the latter being, according to LópezGaliacho Peron (1999: 330), the earliest case of a transsexual marriage (a MTF marrying a man) in Spain.

8 In spite of the legal change of sex and name, the birth certificate of a transsexual person is never altered; a note is added to it recording the change of sex and name.

${ }^{9}$ For an interesting account of the Dutch legislation concerning transsexuality, see Orobio de Castro (1993). Orobio de Castro approaches transsexuality as a "specific 'stage-management- of the interplay of power/knowledge practices in the medical and legal field" (1993: 11). Dutch law is often cited by Spanish authors, such as López-Galiacho Perona (1998).

10 Other worthy initiatives to promote understanding of the transsexualism and transgenderism was carried out by the research network "Sexuality and Society", based in the Sociology Department at the University of Barcelona, which devoted one of the popular summer courses, Els Juliols de la Universitat de Barcelona, to alternative sexualities (Nuñez 2002, Guasch 2002).

11 In Barcelona there are four transsexual associations: Col-lectiu de Transexuals de Catalunya, Grup de Transexuals de Catalunya, Grup de Transexuals Masculins, and Fundación para la Identidad de Género <http://www.figinternet.org/index.html>, Asociación de Transexuales e Intersexuales de Cataluña (ATC) (http://es.geocities.com/atclibertad/). Some transsexual associations, generally from other communities, have become part of the Federación Estatal de Gays, Lesbianas y Transexuales (FELGThttp://www.felgt.org/webportal)

12 To the best of my knowledge, this is the only transsexual association in Spain that has occasionally been also involved with intersexed people, although the Asociación de Transexuales e Intersexuales de Cataluña has this term in its title.

13 For a full history of transsexual's associations in Spain, see Ramos Cantó (2003).

14 Elias et al (1999) compare the "Transgendered Movement" (mainly the US transgendered community) to the Women's Movement, the Civil Rights Movement, and the Gay Movement. They report that the "Transgendered Movement" is "currently undergoing a defining period in which all groups ranging from cross dressers to transsexuals are coming together under the definition of transgender, a still badly defined term". This "Reformist Movement" aims at the social legitimation of their gender position and argues for de- 
pathologising and normativising the condition.

15 This expression refers to Butler's notion of iterability, namely the process by which the repeated citation of gender norms perform bodies and identities. Those citations which deviate from the norm and imply a different gender enactment are qualified as unfaithful.

16 In Spain the terms transvestite and transsexual have different usage than in the UK. In Spain MTF transsexuals are popularly known as 'travestis', a corruption of 'transvestido' (transvestite). Hence, the general public refers to biologically male persons who are interfering with their bodies at hormonal and/or surgical levels as travesti, not as transsexual. In the UK the term 'she-males' roughly corresponds to 'travesti' when applied to persons who have a female appearance but preserve their male genitals. The category 'transvestite' as defined in medical literature and used in the UK corresponds to what in Spain is called transformista, literally one who transforms oneself. The differences in terminology and conceptualisation of transsexuality and sex-gender change can also be observed between the folk knowledge of different cultures, such as in LatinAmerican societies (see, for instance, Kulick 1998 and Prieur 1998).

17 I am grateful to Sra. María Lluisa Fernández for making this information available to me in a very interesting and enlightening interview. Sra. Fernández is the only Spanish lawyer specialising in the defence of transsexuals' cases.

18 Sra. Fernández informs me that lawyers rarely use the term gender, for sex is better understood by judges.

19 It is normal in Spain for transsexuals to live in a pre-operative sex for a long period of time before they go ahead with the sex-change operation (I will expand on this point in the next section). Therefore they are generally surrounded by a social milieu familiarised with their 'new' identity.

20 The medical and legal elite control the concentration of power that arises from routinisation of action and distribution of knowledge. This condensation of power bestows their capacity to direct social routines. However, the case of transsexualism illustrates how the social milieu also holds a parcel of power.

21 In the UK, the incentive for the operation arises from the requirement to undergo a real life test that usually begins before the treatment has been able to produce tangible results. Hence, during the real life test transsexuals make a public commitment as subjects of a particular gender before being able to achieve a successful impersonation and thus pass unproblematically. As consequence of this situation, UK transsexuals feel the need to proceed hastily in the process of subjectification in order to gain social acceptance and avoid punishment. Meyer (1991) agrees with this view in so far as he considers the real life test as a mechanism to transform transsexuals into medical golems whose "redemption" is provided by the very same forces that have created them in the first place in a circular fashion.

${ }^{22}$ A consequence of the lack of institutionalisation is a lack of control on medication: "at the beginning I was taking hormones in heaps. I'm being totally honest to you. I was taking hormones at my own whim" (Elsa).

${ }^{23} \mathrm{An}$ 'O.T.F.' stands for the "Obligatory Transsexual File" (Stone quoted in Hausman 1995: 143) that many Anglo-Saxon transsexual transsexuals keep with information about the condition and general information about treatments. Indeed, the Anglo-Saxon transsexual population in general are renowned for being very well informed on all aspects of gender dysphoria. Many interviewed transsexuals in the UK kept documents, articles, biographies of successful transsexuals, and other informative material.

24 This is particularly visible in Silvia's speech, maybe due to her role as secretary of the CTC.

25 See also Cambassani 2003: 86.

${ }^{26}$ An exception being Seville's archbishop who recently spoke was in favour of transsexual people.

27 I have chosen to make a literal translation of the Spanish expression ir a misa in order to keep the flavour of the idiom. To say that something 'goes to Mass' means that it becomes sacred, hence unchallengeable, such as the sacred words and rites pronounced and performed in the Holy Mass. Thus, Elsa is likening the work of doctors to that of priests to denote that the authority of the medical profession goes unchallenged. The comparison between the medical profession and the Church as two moral orders in the context of transsexualism coincides with Billings and Urban (Billings and Urban 1982).

28 The exception being Mejía (2006), an ethnographical and auto-ethnographical account of transsexualism in Spain, that enriches the understanding of the transsexual collective in the Spanish State but does not make any theoretical contribution. 


\section{References}

BILLINGS, D. B. and Urban, T. (1982), "The Socio-Medical Construction of Transsexualism: an Interpretation and Critique", Social Problems 29 (3). 296-282.

BUTLER, J. (1988), "Performative Acts and Gender Constitution: An Essay in Phenomenology and Feminist Theory", Theatre Journal 40, part 4: 519-31.

BUTLER, J. (1990), Gender Trouble. Feminism and the Subversion of Identity, Routledge, London.

CAMBASSANI, O. (2003) "Test de la vida real: ¿Una mujer más?" in Nieto, J.A. (ed.) (1998)

Transexualidad, transgenerismo y cultura. Antropología, identidad y género, Editorial Talasa, Madrid. 85-95.

ELIAS, J. E.; Elias, V. D.; Rosal, C. L (1999), "Transgender as an emerging social movement", The International Journal of Transgenderism, 3 (3). http://www.symposion.com/ijt/index.htm.

ELÓSEGUI ITXASO, M. (1999), La Transexualidad. Jurisprudencia y argumentación jurídica, Editorial Comares, Granada.

GARFINKEL, H. (1967), Studies in Ethnomethodology, Polity Press, UK.

GUASCG, O.; Adam, A. (eds.) (2002) Sociologia de la Sexualitat.Una Aproximació a la Diversitat Sexual. Pòrtic-Els Juliols, Barcelona.

HAUSMAN, B. (1995), Changing Sex. Transsexualism, Technology, and the Idea of Gender, Duke Universtiy Press, US.

KESSLER, S. J., McKenna, W. (1978), Gender. An Ethnomethodological Approach. John Wiley \& Sons, US.

KULICK, D. (1998), Travestí. Sex, Gender and Culture among Brazilian Transgendered Prostitutes , The University of Chicago Press, US.

LÓPEZ-GALIACHO PERON, J. (1998), La problemática Jurídica de la Transexualidad, McGraw Hill, Madrid.

MARTíN Romero, D. (2004), La Transexualidad, Diversidad de una Realidad, Cuadernos Técnicos de Servicios Sociales, Consejería de Familia y Asuntos Sociales, Comunidad de Madrid, Madrid.

MEYER, M. (1991), "I Dream of Jeannie. Transsexual Striptease as Scientific Display", The Drama Review 35 (1): $25-42$.

NIETO, J.A. (1998), "Transgénero/Transexualidad: de la crisis a la reafirmación del deseo" in Nieto, J.A. (ed.) (1998), Transexualidad, transgenerismo y cultura. Antropología, identidad y género, Editorial Talasa, Madrid. 11-37.

NUÑEZ VIDAL, Esther (2002) "Transsexualisme, transgenerisme i sistemes de gènere" in Oscar Guasch and Antoni Adam (eds.) (2002) Sociologia de la Sexualitat. Una Aproximació a la Diversitat Sexual. PòrticEls Juliols, Barcelona. 123-139.

MEJÍA, Norma (2006) Transgenerismos: Una Experiencia Transexual Desde La Perspectiva Antropológica, Serie General Universitaria, Bellaterra.

OROBIO DE CASTRO, I. (1993), Made to Order. Sex/Gender in a Transsexual Perspective, Het Spinhuis, The Netherlands.

PETERSEN, M. E. and Dickey, R. (1995), "Surgical Sex Reassignment: A Comparative Survey of International Centers", Archives of Sexual Behavior , 24 (2): 135-156.

PRIEUR, A. (1998), Mema's House, Mexico City: on transvestites, queens, and machos, The University of Chicago Press, Chicago.

PURNELL, A. (ed.) (1996), Gendys' 96. The Fourth International Gender Dysphoria Conference , GENDYS Conferences, Derby.

RAMOS CANTÓ, J. (2003) "Las asociaciones de transexuales en España" in Nieto, J.A. (ed.) (1998) Transexualidad, transgenerismo y cultura. Antropología, identidad y género, Editorial Talasa, Madrid. 125142.

RISMAN, B. J. (1982), "The (Mis)Acquisition of Gender Identity Among Transsexuals", Human Science Press, 5 (4) : 312-325. 
SOLEY-BELTRAN, P. (2001), Transsexualism and the Heterosexual Matrix: a Critical and Empirical Study of Judith Butler's Performative Theory of Gender, PhD. Thesis, Science Studies Unit, University of Edinburgh, Scotland, UK.

SOLEY-BELTRAN, P. (2003), "Citaciones perversas? De la distinción sexo-género y sus apropiaciones", in D. Maffia (ed), Sexualidades migrantes: género y transgénero, Feminaria Editorial, Buenos Aires.

VILLALBÍ Godes, Eugeni (2005), El Moviment en imatges. El moviment gai, lesbià i transsexual a Catalunya, Exhibition Catalogue, Departament de la Presidència, Generalitat de Catalunya, Barcelona.

WITTIG, M. ([1976] 1982), "The Category of Sex", Feminist Issues, Fall. 63-8. 